\title{
PRODUCTION, CHARACTERISATION AND VALUE ADDITION OF DAHI MADE FROM RAW, PASTEURIZED AND DOUBLE PASTEURIZED MILK
}

\author{
Sayantani Roy Chowdhury ${ }^{1}$, Arun Kumar Bhattacharyya ${ }^{2}$ \\ ${ }^{I}$ Department of Food Technology, TIFAC-CORE, Techno India, West Bengal, India \\ ${ }^{2}$ Department of Food Technology, TIFAC-CORE, Techno India, West Bengal, India
}

\begin{abstract}
Dahi is an Indian fermented milk product having high nutritive values produced by bacterial fermentation of milk. The main objective of this study is to retain the nutritive value of milk supposedly lost during pasteurization and to compare the anti pathogenic effect of bacterial fermentation and prolonged incubation of dahi from raw milk as cheese from raw milk is approved by FDA regulations provided the ripening is done for a minimum period of 60 days. Further study was undertaken for characterization of the product as dahi based on acidity, acceptability and the microbial count including Lactobacillus and Coliform. Value addition with different herbs and spices was carried out with the intent of observing their two fold effect on dahi as a flavouring agent and their anti Coliform activity. Moreover the anti Coliform activity of these herbs is likely to decrease the drastic thermal processing required to reduce the pathogen count. The setting conditions was optimized at $15 \mathrm{hrs}$ of incubation time, $37^{\circ} \mathrm{C}$ temperature and with an inoculum volume of 5\%. The factors involved were acidity, overall acceptability and total microbial count based on the interactive effect of timetemperature profile and inoculum volume. Further scope of study may include standardization of the process of inclusion of herbs and spices based on its nutritive, flavouring and anti-microbial properties.
\end{abstract}

Keywords: pasteurization, value addition, dahi, Lactobacillus, flavouring, herbs and spices, anti-Coliform effect $* * *$

\section{INTRODUCTION}

Indian yogurt, known as dahi, is a well-known fermented milk product consumed by large sections of the population throughout the country, either as a part of the daily diet or as a refreshing beverage. Since conversion of milk into dahi is an important intermediary step in the manufacture of indigenous butter and ghee, it can be said that over 40 percent of the total milk production in India today is converted into dahi [1]

According to the PFA Rules (1976), dahi is the product obtained from pasteurized or boiled milk by souring, natural or otherwise, by a harmless lactic acid or other bacterial culture. Dahi may contain additional cane sugar. It should have the same percentage of fat and solid-not-fat as the milk from which it is prepared. Where dahi, other than skimmed milk dahi, is sold or offered for sale without any indication of the class of milk, the standards prescribed for dahi prepared from buffalo milk shall apply.

Dahi is a very good source of calcium, phosphorus, riboflavinvitamin B2 and iodine. Dahi also is a good source of vitamin B12, pantothenic acid-vitamin B5, zinc, potassium, protein and molybdenum. These 10 nutrients alone would make dahi a health-supportive food. But some of the most interesting health information about dahi comes from a different context- its potential inclusion of live bacteria. Dahi has been attributed neutraceutical, therapeutic and probiotic effects, such as digestion enhancement, immune system boosting, anticarcinogenic activity and reduction in serum cholesterol.

The main raw material of dahi processing is milk which is an excellent medium for microbiological growth and when stored at ambient temperature bacteria and other pathogens are soon proliferating. To render milk safe for human consumption by destruction of pathogenic micro-organism and to improve the keeping quality of milk by destruction of spoilage micro organism, pasteurization of milk is done.

But there are certain disadvantages of pasteurization process. It encourages slackening of efforts for sanitary milk production and it may be used to mask low-quality milk. Pasteurization process also reduces the cream line or cream volume of the milk. Another side effect of the heating of pasteurization is that some vitamin, and beneficial (or probiotic) bacteria is lost. Pasteurization temperature does not affect fat-soluble vitamins (A, D, and E), as well as the Bcomplex vitamins riboflavin, pantothenic acid, biotin, and niacin. The losses of vitamins, such as thiamin $(<3 \%)$, pyridoxine $(0-8 \%)$, cobalamin $(<10 \%)$, and folic acid $(<10 \%)$ are considered lower than those that take place during the normal handling and preparation of foodstuffs at home (Lund, 
1982). Most of the vitamin $\mathrm{C}$ is lost during handling, pasteurization, packaging, and oxidation of milk; about $70 \%$ of the remaining vitamin $\mathrm{C}$ and $90 \%$ of riboflavin can be destroyed by sunlight exposure during storage (Renner, 1986)[2]. Because nutrient losses are small in comparison to the large amount of the two B-vitamins present, but it continues to provide significant amounts of thiamin and vitamin B12 and that as milk is not an important dietary source of vitamin $\mathrm{C}$, its loss is not nutritionally significant. Besides all the above disadvantages pasteurization is the only effective way of killing most pathogenic bacteria. Normally high temperature short time (HTST) pasteurization $\left(72^{\circ} \mathrm{C}\right.$ for 15 seconds) is applied.

Proponents of non-pasteurized raw milk credit it with having more beneficial bacteria and enzymes than its processed counterpart and argue that milk drinkers should legally be allowed to choose their preferred level of risk vs. benefit.

Proponents of unpasteurized milk make the argument that if milk is obtained from humanely raised cows that are grass fed and handled hygienically, then there is little problem with disease.

However, raw milk can become contaminated in a number of ways: by coming into contact with cow feces or bacteria living on the skin of cows, from an infection of the cow's udder, or from dirty equipment, among others.

Raw milk is far more likely to contain harmful microbial contaminants, and that pasteurization is the only effective way of killing most pathogenic bacteria. The HTST pasteurization standard was designed to achieve a five-log reduction, killing $99.999 \%$ of the number of viable micro-organisms in milk. This is considered adequate for destroying almost all yeasts, molds and common spoilage bacteria and also to ensure adequate destruction of common pathogens. But there is also a chance of contamination after pasteurization if pasteurized milk is not handled properly.

In some European country cheese made from raw milk plays a great role, but The FDA's strong concern for consumer expectations of safety led it to set the aging requirement at 60 days with very little scientific evidence to support such specific duration regardless of cheese variety. In its rulemaking release, the agency admitted as much:

"Viable pathogenic microorganisms in cheese, even when present to such an extent as to be capable of causing disease in humans, tend to die when the cheese is held for some time at temperatures above $350 \mathrm{~F}$. It is not known with certainty how long cheeses must be held before they become safe. No outbreak has been reported from cheese held 60 days or more." [3]
The release in the Federal Register, in the year 1949[3] reveals two fundamental agency attitudes toward protection of consumers:

(1)that aging requirements should be as long as necessary to replicate the safety provided by pasteurization of milk, and (2) that pasteurization of milk provided a complete promise of consumer safety.

There has been much research on yogurt preparation from different sources [4,5], but there has been little information on the retention of milk nutrients in yogurt, preparation of dahi from raw milk and anti pathogenic effect of bacterial fermentation of dahi. Therefore our study was carried out to retain the nutritive value of milk supposedly lost during pasteurization and to compare the anti pathogenic effect of bacterial fermentation and prolonged incubation of dahi from raw milk. In the present study characterization of the product as dahi based on acidity, acceptability and the microbial count including Lactobacillus and Coliform also carried out. Value addition with aqueous extract of different herbs and spices were carried out with the intent of observing their two fold effect on dahi as a flavouring agent and their anti coliform activity.

\section{MATERIALS AND METHODS}

\subsection{Materials}

Raw milk which is used for this study is collected from the local milk man. Milk is collected from the milk man in a previously cleaned and washed (hot water washing) PET bottle and is kept at refrigeration temperature. Amul pasteurized toned milk, Amul Masti dahi which was used as inoculums, nutmeg and mint leaves were collected from local market of Kolkata, West Bengal, India.

\subsection{Methods}

\subsubsection{Standardization of Inoculums Volume}

To study the effect of pasteurization, raw material i.e. milk was pre-treated in different ways such as :

- Raw milk without any heat treatment (sample-1)

- Raw milk heated at $60^{\circ} \mathrm{C}$ for $1 \mathrm{~min}$ (sample-2)

- Pasteurized toned milk (sample- 3)

- Pasteurized toned milk heated at $72^{\circ} \mathrm{C}$ for $1 \mathrm{~min}$ (sample- 4)

- Pasteurized toned milk heated at $90^{\circ} \mathrm{C}$ for $1 \mathrm{~min}($ sample- 5) ( taken as control)

- Pasteurized toned milk previously held at room temperature for 4 hours (sample- 6)

- Pasteurized toned milk previously held at room temperature for 4 hours, and then heated at $72^{\circ} \mathrm{C}$ for $1 \mathrm{~min}$ (sample- 7)

Previously treated milk was inoculated with the varying concentration $(5 \%, 10 \%, 15 \%, 20 \%)$ of inoculums in washed 
plastic cups (plastic cups are cleaned and washed at $80-85^{\circ} \mathrm{C}$ for few seconds). Cups were then sealed with aluminium foil and incubated at $37^{\circ} \mathrm{C}$ temperature for 15 hours. After incubation, cups were placed at refrigerator.

Physical parameters (setting and flavor) were measured with the help of an expert panel of judges from Techno India. For evaluation of the response, a 5 point scale with the following qualitative designation and corresponding points are used as mentioned below:

a) Liked definitely (LD):5

b) Liked mildly(LM):4

c) Neither liked nor disliked (NLND):3

d) Disliked mildly(DM):2

e) Disliked definitely (DD): 1

Chemical test (acidity) was done as per method described in A.O.A.C(1982).

\subsubsection{Study of Effect of Milk Solid Percentage on Setting of Dahi}

Skimmed Milk Powder was added according to the total solid percentage of the raw materials to make the total solid percentage $14 \%$ approximately and then the milk was treated according to the previously mentioned process. Then it was inoculated with $5 \%$ inoculums in washed plastic cups (plastic cups are cleaned and washed at $80-85^{\circ} \mathrm{C}$ for few seconds). Cups were then sealed with aluminium foil and incubated at $37^{\circ} \mathrm{C}$ for 15 hours. After incubation, cups were placed at refrigerator.

Physical parameters (setting and flavor) and chemical test (acidity) were done as per method described in standardization of inoculums volume (2.2.1). Microbiological test (LAB count) was done as per method described in A.O.A.C(1982).

\subsubsection{Preparation of Herbal Extracts}

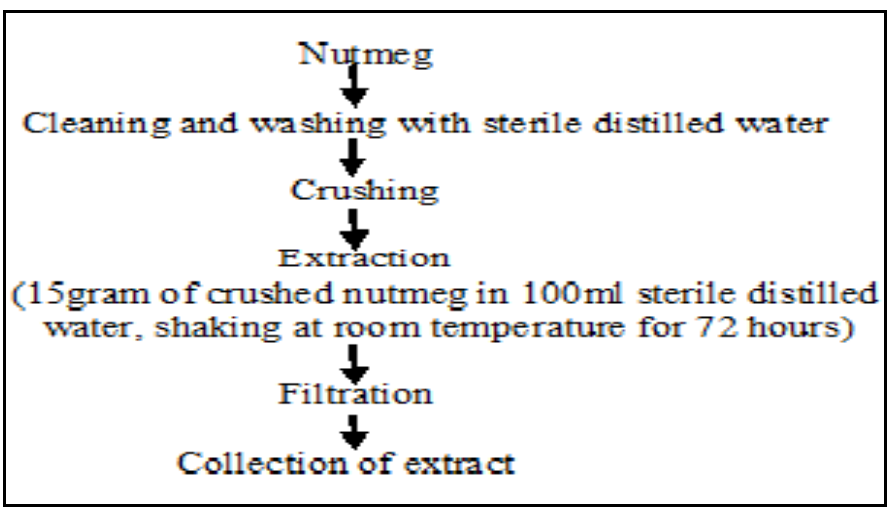

Fig 1: Preparation of Nutmeg Extract

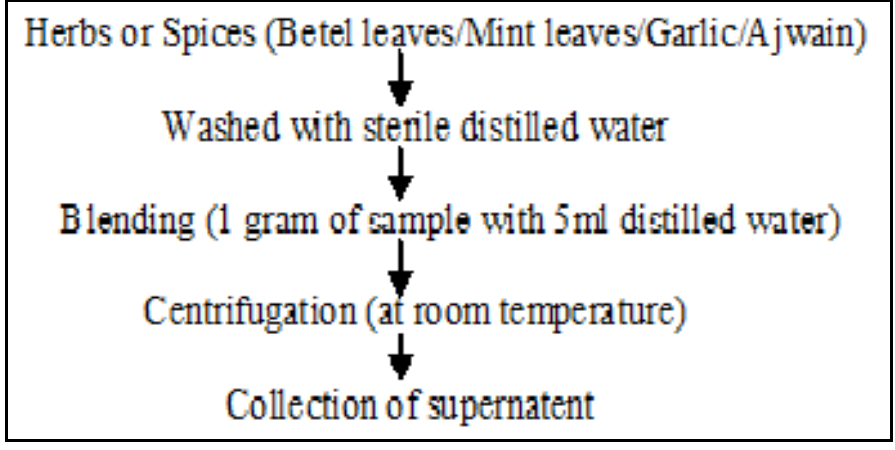

Fig 2: Preparation of herbal Extract

\subsubsection{Estimation of Effectiveness of Nutmeg and} Herbal Extract against E. coli by Zone of Inhibition

\section{Method}

To determine whether nutmeg extract and herbal extracts were effective against E. coli or not, zone of inhibition method was adopted. To obtain direct counts of E. coli, 15-20ml sterile, molten $\left(40-45^{\circ} \mathrm{C}\right)$ EMB Agar media was poured into sterile petri dishes containing $1 \mathrm{ml}$ of standard E. coli culture which was isolated from milk. Inoculums were distributed throughout the medium by rotating the plate in one direction and then in the reverse direction. The medium was allowed to solidify on a flat surface for 5-10 min. After solidification, bore-wells were made on the petri dishes and marked. Nutmeg and the herbal extracts were poured in the respective bore. Then the plates were incubated at $37^{\circ} \mathrm{C}$ for $24-48$ hours. Colonies of $\mathrm{E}$. coli have a characteristic green metallic sheen. Zone of inhibition is measured by the difference in the radius of the inhibited zone where the growth of E. coli was not seen along the diameter of the bore.

\subsubsection{Characterization of Value Added Dahi}

Nutmeg extracts and the herbal extracts were added to previously treated (mentioned in section 2.2.1) standardized (total solid percentage of milk 14\%). Then it was inoculated with $5 \%$ inoculums in washed plastic cups (plastic cups are cleaned and washed at $80-85^{\circ} \mathrm{C}$ for few seconds). Cups were then sealed with aluminium foil and incubated at $37^{\circ} \mathrm{C}$ for 15 hours. After incubation, cups were placed at refrigerator.

Physical parameters (setting and flavor) and chemical test (acidity) were done as per method described in standardization of inoculums volume.

\subsubsection{Standardization of Herbal Extracts Percentage}

Standardization of herbal extract percentage was done on the basis of sensory attributes of dahi and also on the basis of their ability to inhibit the E. coli present on the milk. Pasteurized toned milk was heated at $72^{\circ} \mathrm{C}$ for $1 \mathrm{~min}$ and cooled to room temperature. Various percentages of nutmeg and mint leaves 
extracts $(5 \%, 10 \%, 15 \%)$ and $1 \mathrm{ml}$ of $E$. coli culture were added to the milk. Then each portion of milk was inoculated with 5\% inoculums in washed plastic cups (plastic cups are cleaned and washed at $80-85^{\circ} \mathrm{C}$ for few seconds). Cups were then sealed with aluminium foil and incubated at $37^{0} \mathrm{C}$ for 15 hours. After incubation, cups were placed at refrigerator. Control was prepared also by following the same steps without addition nutmeg and mint leaves extract.

Physical parameters (setting and flavor) and chemical test (acidity) were done as per method described in standardization of inoculums volume. Microbiological test (LAB count, Coliform count) was done as per method described in A.O.A.C (1982).

\section{RESULTS AND DISCUSSION}

\subsection{Standardization of Inoculums Volume}

Standardization of inoculums volume was carried out on the basis of sensory analysis and percentage of acidity ( in terms of lactic acid) developed in the final product i.e. dahi.

Table-1 Standardization of inoculum volume (trial-1)

\begin{tabular}{|c|c|c|c|c|c|c|}
\hline $\begin{array}{l}\text { Sam } \\
\text { ple }\end{array}$ & $\begin{array}{l}\text { Incub } \\
\text { ation } \\
\text { time }\end{array}$ & $\begin{array}{l}\text { Incub } \\
\text { ation } \\
\text { tempe } \\
\text { rature }\end{array}$ & $\begin{array}{l}\text { Inoculu } \\
\text { ms } \\
\text { volume }\end{array}$ & $\begin{array}{l}\text { Sensor } \\
\mathrm{y} \text { score } \\
\text { for } \\
\text { setting } \\
\text { of dahi }\end{array}$ & $\begin{array}{l}\text { Sensor } \\
\text { y score } \\
\text { for } \\
\text { flavor } \\
\text { profile } \\
\text { of dahi }\end{array}$ & $\begin{array}{l}\% \text { of } \\
\text { Acidi } \\
\text { ty(in } \\
\text { terms } \\
\text { of } \\
\text { lactic } \\
\text { acid) }\end{array}$ \\
\hline 1 & \multirow{7}{*}{$\begin{array}{c}15 \\
\text { hours }\end{array}$} & \multirow{7}{*}{$37^{\circ} \mathrm{C}$} & \multirow{7}{*}{$5 \%$} & 2 & 2 & 0.775 \\
\hline 2 & & & & 2.5 & 3.25 & 0.469 \\
\hline 3 & & & & 3.25 & 3 & 0.496 \\
\hline 4 & & & & 3.75 & 3 & 0.633 \\
\hline 5 & & & & 4.25 & 4 & 0.673 \\
\hline 6 & & & & 2 & 3 & 1.006 \\
\hline 7 & & & & 4.5 & 3.75 & 0.548 \\
\hline
\end{tabular}

Table: 2 Standardization of inoculum volume (trial-2)

\begin{tabular}{|c|c|c|c|c|c|c|}
\hline $\begin{array}{l}\text { Sam } \\
\text { ple }\end{array}$ & $\begin{array}{c}\text { Incubat } \\
\text { ion } \\
\text { time }\end{array}$ & $\begin{array}{c}\text { Incubati } \\
\text { on } \\
\text { tempera } \\
\text { ture }\end{array}$ & $\begin{array}{l}\text { Inocul } \\
\text { ums } \\
\text { volume }\end{array}$ & $\begin{array}{c}\text { Sens } \\
\text { ory } \\
\text { score } \\
\text { for } \\
\text { settin } \\
\mathrm{g} \text { of } \\
\text { dahi }\end{array}$ & $\begin{array}{c}\text { Sens } \\
\text { ory } \\
\text { score } \\
\text { for } \\
\text { flavo } \\
\text { r } \\
\text { profil } \\
\text { e of } \\
\text { dahi }\end{array}$ & $\begin{array}{l}\% \text { of } \\
\text { Acidi } \\
\text { ty( in } \\
\text { terms } \\
\text { of } \\
\text { lactic } \\
\text { acid) }\end{array}$ \\
\hline 1 & \multirow[b]{3}{*}{15} & \multirow[b]{3}{*}{$37^{\circ} \mathrm{C}$} & \multirow[b]{3}{*}{$10 \%$} & 1 & 1 & 0.361 \\
\hline 2 & & & & 1 & 1.5 & 0.214 \\
\hline 3 & & & & 3.5 & 1 & 0.807 \\
\hline
\end{tabular}

\begin{tabular}{|l|l|l|l|c|c|c|}
\hline 4 & hours & \multirow{3}{*}{} & & 3.5 & 3 & 0.359 \\
\hline 5 & & 4 & 3 & 0.645 \\
\hline \multirow{2nnnyy}{*}{} & \multirow{5}{*}{} & & 4 & 1.5 & 0.841 \\
\hline 7 & & & 4 & 1.5 & 0.566 \\
\hline
\end{tabular}

Table-3 Standardization of inoculum volume (trial-3)

\begin{tabular}{|c|c|c|c|c|c|c|}
\hline $\begin{array}{l}\text { Sam } \\
\text { ple }\end{array}$ & $\begin{array}{l}\text { Incuba } \\
\text { tion } \\
\text { time }\end{array}$ & $\begin{array}{l}\text { Incubati } \\
\text { on } \\
\text { tempera } \\
\text { ture }\end{array}$ & $\begin{array}{l}\text { Inocul } \\
\text { ums } \\
\text { volum } \\
\mathrm{e}\end{array}$ & $\begin{array}{l}\text { Sens } \\
\text { ory } \\
\text { score } \\
\text { for } \\
\text { settin } \\
\mathrm{g} \text { o } \\
\text { dahi }\end{array}$ & $\begin{array}{l}\text { Sens } \\
\text { ory } \\
\text { score } \\
\text { for } \\
\text { flavo } \\
\mathrm{r} \\
\text { profil } \\
\mathrm{e} \text { of } \\
\text { dahi }\end{array}$ & $\begin{array}{l}\% \text { of } \\
\text { Acidit } \\
y(\text { in } \\
\text { terms } \\
\text { of } \\
\text { lactic } \\
\text { acid) }\end{array}$ \\
\hline 1 & \multirow{7}{*}{$\begin{array}{c}15 \\
\text { hours }\end{array}$} & \multirow{7}{*}{$37^{\circ} \mathrm{C}$} & \multirow{7}{*}{$15 \%$} & 3 & 2 & 0.556 \\
\hline 2 & & & & 3.5 & 4 & 0.584 \\
\hline 3 & & & & 2 & 1 & 0.465 \\
\hline 4 & & & & 4 & 4 & 0.717 \\
\hline 5 & & & & 4 & 4 & 0.674 \\
\hline 6 & & & & 2.5 & 2.5 & 0.747 \\
\hline 7 & & & & $\begin{array}{c}\mathrm{COB} \\
\text { posit } \\
\text { ve }\end{array}$ & $\begin{array}{l}\text { COB } \\
\text { positi } \\
\text { ve }\end{array}$ & $\begin{array}{c}\mathrm{COB} \\
\text { positiv } \\
\mathrm{e}\end{array}$ \\
\hline
\end{tabular}

Table-4 Standardization of inoculum volume (trial-4)

\begin{tabular}{|c|c|c|c|c|c|c|}
\hline $\begin{array}{c}\text { Sam } \\
\text { ple }\end{array}$ & $\begin{array}{c}\text { Incubat } \\
\text { ion } \\
\text { time }\end{array}$ & $\begin{array}{l}\text { Incubati } \\
\text { on } \\
\text { tempera } \\
\text { ture }\end{array}$ & $\begin{array}{c}\text { Inocul } \\
\text { ums } \\
\text { volume }\end{array}$ & $\begin{array}{c}\text { Sens } \\
\text { ory } \\
\text { score } \\
\text { on } \\
\text { settin } \\
\text { g of } \\
\text { dahi }\end{array}$ & $\begin{array}{c}\text { Sens } \\
\text { ory } \\
\text { score } \\
\text { on } \\
\text { flavo } \\
\text { r of } \\
\text { dahi }\end{array}$ & $\begin{array}{l}\% \text { of } \\
\text { Acidi } \\
\text { ty( in } \\
\text { terms } \\
\text { of } \\
\text { lactic } \\
\text { acid) }\end{array}$ \\
\hline 1 & \multirow{7}{*}{$\begin{array}{c}15 \\
\text { hours }\end{array}$} & \multirow{7}{*}{$37^{\circ} \mathrm{C}$} & \multirow{7}{*}{$20 \%$} & 2.5 & 1.75 & 0.723 \\
\hline 2 & & & & 1 & 2 & 0.630 \\
\hline 3 & & & & 2.5 & 2.5 & 0.674 \\
\hline 4 & & & & 3.25 & 3.25 & 0.740 \\
\hline 5 & & & & 3.75 & 4 & 0.703 \\
\hline 6 & & & & 3.5 & 2.75 & 0.879 \\
\hline 7 & & & & 3 & 3.5 & 0.700 \\
\hline
\end{tabular}

From the above results, we can conclude that at $37^{\circ} \mathrm{C}$ temperature and 15 hours incubation time, 5\% inoculums volume yielded the best results in terms of acidity as well as sensory analysis on the basis of control which is sample number 5 (Pasteurized toned milk heated at $90^{\circ} \mathrm{C}$ for $1 \mathrm{~min}$ ). But the setting of all dahi samples and the percentage of acidity is not satisfactory. Reason of improper setting and the percentage of acidity may be lower due to the total solid percentage in milk. To overcome this problem another study is done by increasing the total solid percentage of milk up to 
$14 \%$ approximately by addition of skimmed milk powder. According to the standard procedure milk which is used for the dahi preparation contains $2.5-3.0 \%$ fat and $10 \%$ solid not fat which ensure the desirable body, flavor and acidity $(0.75$ $0.85 \%$ lactic acid) of the final product [1].

\subsection{Study of Effect of Milk Solid Percentage on}

\section{Setting of Dahi}

In conventional method milk is standardized to 2.5-3.0 percent fat and 10 percent solid not fat to improve the body of dahi. But in the previous trial for Standardization of inoculums volume is done, total milk solid percentage is not adjusted which may be one of the reasons for improper setting of dahi. To overcome this problem, milk solid percentage is adjusted to $14 \%$ approximately.

Increased percentage of acidity (in terms of lactic acid) and proper setting of dahi (Table-5) proved that standardization of milk i.e. total solid percentage up to $14 \%$ is needed before dahi production.

Table-5 Study of sensory analysis and \% of acidity (in terms of lactic acid) after addition of skimmed milk powder (milk solid $=14 \%$ approx.)

\begin{tabular}{|c|c|c|c|c|c|c|}
\hline $\begin{array}{l}\text { Sam } \\
\text { ple }\end{array}$ & $\begin{array}{l}\text { Incubat } \\
\text { ion } \\
\text { time }\end{array}$ & $\begin{array}{l}\text { Incubati } \\
\text { on } \\
\text { tempera } \\
\text { ture }\end{array}$ & $\begin{array}{l}\text { Inocul } \\
\text { ums } \\
\text { volume }\end{array}$ & $\begin{array}{l}\text { Sens } \\
\text { ory } \\
\text { score } \\
\text { for } \\
\text { settin } \\
\mathrm{g} \text { of } \\
\text { dahi }\end{array}$ & $\begin{array}{l}\text { Sens } \\
\text { ory } \\
\text { score } \\
\text { for } \\
\text { flavo } \\
\text { r } \\
\text { profil } \\
\text { e of } \\
\text { dahi }\end{array}$ & $\begin{array}{l}\% \text { of } \\
\text { Acidi } \\
\text { ty( in } \\
\text { terms } \\
\text { of } \\
\text { lactic } \\
\text { acid) }\end{array}$ \\
\hline 1 & \multirow{7}{*}{$\begin{array}{l}15 \\
\text { hours }\end{array}$} & \multirow{7}{*}{$37^{\circ} \mathrm{C}$} & \multirow{7}{*}{$5 \%$} & 3.5 & 2.66 & 1.13 \\
\hline 2 & & & & 2.83 & 3.66 & 0.738 \\
\hline 3 & & & & 3.5 & 3.5 & 1.01 \\
\hline 4 & & & & 4.33 & 3.5 & 0.757 \\
\hline 5 & & & & 4.66 & 4 & 0.913 \\
\hline 6 & & & & 3.83 & 3.75 & 0.729 \\
\hline 7 & & & & 3.33 & 3.25 & 1.01 \\
\hline
\end{tabular}

\subsection{Estimation of Effectiveness of Nutmeg and Herbal}

\section{Extract against E. coli by Zone of Inhibition Method}

From the literature review, it is revealed that different herbs and spices have antimicrobial activity against E.coli and other pathogenic microorganism $[6,7,8,9,10]$.

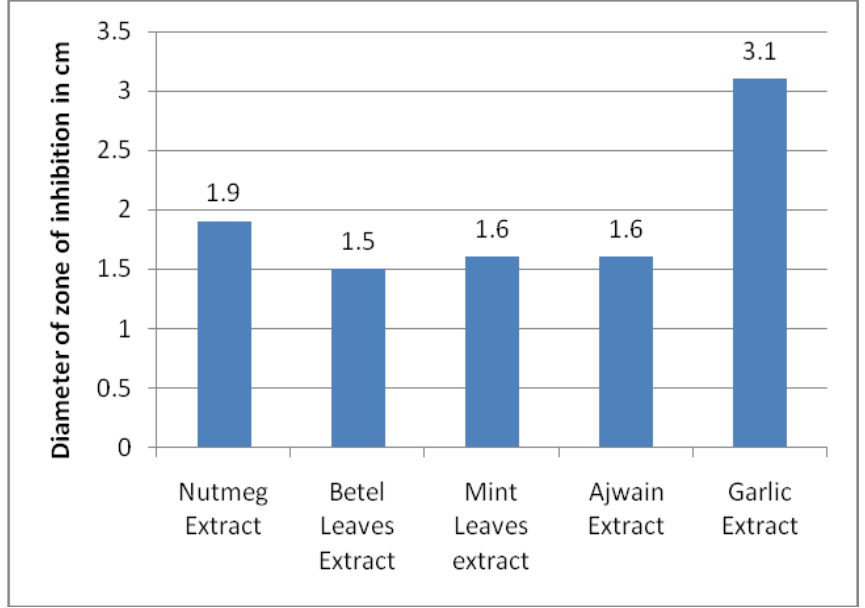

Chart 1: Zone of Inhibition of Nutmeg extract and herbal extracts against standard E. coli

The above result shows that the water extract of nutmeg and other herbs such as betel leaves, mint leaves, ajwain and garlic gives a satisfactory zone of inhibition against standard E. Coli culture. It also proves the effectiveness of nutmeg and other herbal extract against E. Coli culture.

\subsection{Characterization of Value Added Dahi}

Chart 2 shows the sensory score of dahi where 5\% aqueous extract of different herbs and spices were added. Expert panellists of Techno India judged physical parameters (setting and flavour) of dahi with respect to control where no flavouring agent was added. Sensory score for setting and flavour profile of dahi made with 5\% nutmeg extract and 5\% mint leaves extract gives the best result with respect to control. Where flavour profile and setting of dahi for the others were not up to the mark. Setting of dahi made with $5 \%$ garlic and $5 \%$ ajwain extract was improper due to their strong antimicrobial activity against LAB.

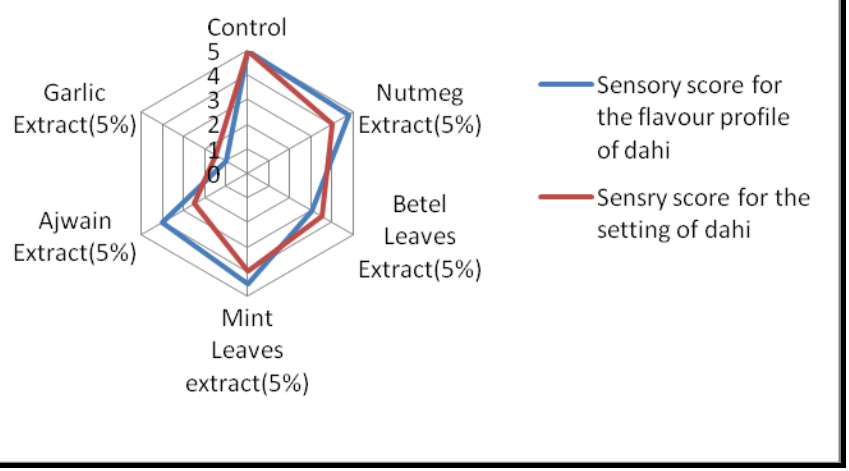

Chart 2: Characterization of value added dahi 


\subsection{Standardization of Herbal Extract Percentage}

Table 6: Standardization of Nutmeg Extract (NE) percentage

\begin{tabular}{|l|l|l|l|l|l|}
\hline $\begin{array}{l}\text { Sample } \\
\text { name }\end{array}$ & $\begin{array}{l}\text { Sens } \\
\text { ory } \\
\text { score } \\
\text { for } \\
\text { setti } \\
\text { ng of } \\
\text { dahi }\end{array}$ & $\begin{array}{l}\text { Sensory } \\
\text { score for } \\
\text { flavour } \\
\text { of dahi }\end{array}$ & $\begin{array}{l}\text { \% of } \\
\text { Acidity } \\
\text { (in } \\
\text { terms } \\
\text { of } \\
\text { lactic } \\
\text { acid) }\end{array}$ & $\begin{array}{l}\text { LAB } \\
\text { Count } \\
(\mathrm{cfu} / \mathrm{ml})\end{array}$ & $\begin{array}{l}\text { Colifor } \\
\mathrm{m} \text { count } \\
(\mathrm{cfu} / \mathrm{ml})\end{array}$ \\
\hline Control & 5 & 5 & 0.842 & $4.5 \mathrm{X} 105$ & $\begin{array}{l}\text { Innumer } \\
\text { able }\end{array}$ \\
\hline NE 5\% & 3.7 & 3.7 & 0.884 & $4.4 \mathrm{X} 105$ & 32 \\
\hline $\begin{array}{l}\text { NE } \\
10 \%\end{array}$ & 3.32 & 3.25 & 0.784 & $1.57 \mathrm{X} 105$ & 26 \\
\hline $\begin{array}{l}\text { NE } \\
15 \%\end{array}$ & 3.16 & 3.16 & 0.877 & $1 \mathrm{X} 105$ & 10 \\
\hline
\end{tabular}

Table 7: Standardization of Mint Leaves Extract (MLE) percentage

\begin{tabular}{|l|l|l|l|l|l|}
\hline $\begin{array}{l}\text { Sample } \\
\text { name }\end{array}$ & $\begin{array}{l}\text { Senso } \\
\text { ry } \\
\text { score } \\
\text { for } \\
\text { settin } \\
\text { g of } \\
\text { dahi }\end{array}$ & $\begin{array}{l}\text { Sensory } \\
\text { score } \\
\text { for } \\
\text { flavour } \\
\text { of dahi }\end{array}$ & $\begin{array}{l}\text { \% of } \\
\text { Acidi } \\
\text { ty (in } \\
\text { terms } \\
\text { of } \\
\text { lactic } \\
\text { acid }\end{array}$ & $\begin{array}{l}\text { LAB } \\
\text { Count } \\
\text { (cfu/ml) }\end{array}$ & $\begin{array}{l}\text { Coliform } \\
\text { count } \\
\text { (cfu/ml) }\end{array}$ \\
\hline Control & 5 & 5 & 0.842 & $4.5 \times 105$ & $\begin{array}{l}\text { Innumera } \\
\text { ble }\end{array}$ \\
\hline MLE 5\% & 3.625 & 3.5 & 0.843 & $3.84 X 105$ & 61 \\
\hline $\begin{array}{l}\text { MLE } \\
10 \%\end{array}$ & 3.5 & 3.25 & 0.882 & 1 X105 & 42 \\
\hline $\begin{array}{l}\text { MLE } \\
15 \%\end{array}$ & 3.88 & 3.5 & 0.770 & $1 X 104$ & 26 \\
\hline
\end{tabular}

\section{CONCLUSIONS}

The above study revealed that the product (dahi) can be developed with pasteurised, double pasteurised and even with the raw milk with effect to varied heat treatment prior to setting of dahi. Value addition with mint leaves and nutmeg extract was carried out with the intent of observing their effect on dahi as a flavouring agent and their anti Coliform activity. This may be concluded that $5 \%$ nutmeg extract scored highest with respect to sensory analysis, based on setting and flavour profile whereas $15 \%$ mint leaves extract was found suitable in this regard. Considering the safety aspect of the processed product, the E. coli count was found to be decreased with increase in concentration of nutmeg and mint leaves extracts. $15 \%$ of NE could be a better alternative than $5 \%$ considering the sensory along with the safety aspects where the destruction of coliform would be pronounced with a high sensory score.

\section{ACKNOWLEDGEMENTS}

Authors gratefully acknowledge Techno India for infrastructural facilities.

\section{REFERENCES}

[1]. Sukumar Dey, Outlines of Dairy Technology, Oxford University Press, 2008

[2]. Valente B. Alvarez and Francisco Parada-Rabell,Health Benefits, Risks, and Regulations of Raw and

Pasteurized Milk, Fact Sheet Extension, The Ohio State University, FSE-3-05

[3]. Laura P. Knoll, Origins of the Regulation of Raw Milk Cheeses In the United States(2005 Third year paper), Digital Access to Scholarship at Harvard Repository.

[4]. Samadrita Sengupta, Jayati Bhowal and D. K. Bhattacharyya, Development of new kinds of soy yogurt containing functional lipids as superior quality food, Annals of Biological Research, 2013, 4 (4):144-151 (http://scholarsresearchlibrary.com/archive.html)

[5]. K.O. Amanze, Quality Evaluation of Yogurt From Cowmilk, Soymilk And Cow/Soymilk, Jorind 9(2) December, 2011. ISSN 1596 - 8308. www.transcampus.org, www.ajol.info/journals/jorind

[6]. Savita Aggarwal And Sanjay Goyal, In Vitro Antimicrobial Studies Of Trychyspermum ammi, International Journal of Pharma and Bio Sciences, Int J Pharm Bio Sci 2012 Oct; 3(4): (P) $64-68$

[7]. Basheer A. Al-Sum, Abdullah A. Al-Arfaj, Antimicrobial activity of the aqueous extract of mint plant, Science Journal of Clinical Medicine 2013; 2(3): 110-113 Published online June 30, 2013 (http://www.sciencepublishinggroup.com/j/sjcm) doi: $10.11648 /$ j.sjcm.20130203.19

[8]. S.K. Prakash, Effects of herbal Extracts Towards Microbicidal Activity Against Pathogenic Escherichia coli in Poultry, International Journal of Pou;try Science 5 (3): 259261, 2006 ISSN 1682-8356

[9]. Peter B. Bongiorno, Patrick M. Fratellone, Pina Lo Giudice, Potential Health Benefits of Garlic (Allium

Sativum): A Narrative Review, Journal of Complementary and Integrative Medicine Volume 5, Issue 12008 Article 1

[10]. Takikawa A, Abe K, Yamamoto M, Ishimaru S, Yasui M, Okubo Y, Yokoigawa K, Antimicrobial activity of nutmeg against Escherichia coli O157, J Biosci Bioeng, 2002;94(4):315-20 